1991

\title{
Saint Vincent de Paul: A Creative Reconciler
}

Margaret John Kelly D.C.

Follow this and additional works at: https://via.library.depaul.edu/vhj

\section{Recommended Citation}

Kelly, Margaret John D.C. (1991) "Saint Vincent de Paul: A Creative Reconciler," Vincentian Heritage Journal: Vol. 12: Iss. 1, Article 6.

Available at: https://via.library.depaul.edu/vhj/vol12/iss1/6

This Article is brought to you for free and open access by the Vincentian Journals and Publications at Digital Commons@DePaul. It has been accepted for inclusion in Vincentian Heritage Journal by an authorized editor of Digital Commons@DePaul. For more information, please contact digitalservices@depaul.edu. 


\title{
Saint Vincent de Paul: A Creative Reconciler
}

\author{
By Margaret John Kelly, D.C. ${ }^{1}$
}

One of the most pervasive themes of Vatican II, whether it be in its discussions of religious liberty, liturgy, or the renewal of the religious life, is its insistence on the historical perspective, the return to one's roots and primitive spirit. The Catholic Church thus reiterated what wise people have consistently warned us about, that when we ignore or forget our past, we run the risk of losing hope and repeating mistakes. To seek out the roots of the modern charities movement, one would have to go to France in the seventeenth century and the work of Saint Vincent de Paul. Before one can move from the twentieth century to the seventeenth century, however, it is important to reflect on two basic questions. The first, why should we remember people and events of the past? The second, do people make the times or do the times form the people? Or, to phrase the two questions as one: is it possible to affect the course of history working out its plan inexorably and independently of human intervention?

First, we remember, we celebrate past events and people because it is the human and thus the Christian thing to do. Our alpha is our omega. In the central mystery of our faith we are told, "Do this in memory of me." Commentators say it is extremely important to remember our past when the present is difficult and our future is uncertain. Psychologists warn that it is not our remembered past that causes us problems but our unremembered past. The Catholic Church is able to serve and advocate at the end of this twentieth century because Vincent de Paul who lived in the seventeenth century provided a blueprint and model. As we reflect on his past and our traditions, we get a sense of history, a sense 
of perspective, and with that a Christian sense of humor which protects us from both false optimism and faithless pessimism. It gives us a deepened faith in God and humble confidence in ourselves. As Elie Wiesel, the eminent writer of the Holocaust, observed recently, "Memory is a shield." ${ }^{2}$

Our second question has challenged people throughout history. Do people make the times or do times make the people? Can we change the course of history as we see it laid out before us or are we just part of a process which goes on independent of our efforts? As we remember Vincent dePaul(1581-1660), weare reassured that indeed one individual, and indeed each of us, can make a decided difference in the course of history. This is a very important conviction to internalize as we experience the depersonalized, dehumanized society conjured up by George Orwell in his novels. We are also facing the year 2000, the millennium which William Butler Yeats warned us is the period "when the rough beast slouches toward Bethlehem to be born," a pessimistic, negative image which appears to reverse the Christian tradition of two thousand years. ${ }^{3}$ The council fathers of Vatican II described our era as one of "supreme crisis" in this "theater of human history" and identified the challenge of bringing to bear the gospel values on contemporary events. ${ }^{4}$ Our bishops chose to reiterate that in their recent statement on justice. ${ }^{5}$

It appears, then, that there is an interactive process operative between each historical period and the people who live in it which can effect monumental advances and changes, but those changes are motivated and achieved only through the alchemy of leadership. Vincent de Paul changed history because he was a creative reconciler. Thus we remember Vincent because he took the varied, at times conflicting and competing, interests of the seventeenth century and with inventiveness initiated activities which not only addressed the problems of his day, but have also influenced the course of history throughout the intervening years. He was not content to ponder problems endlessly or seek to pass blame and responsibility for difficult situations.

\footnotetext{
${ }^{2}$ Personal communication.

${ }^{3}$ William Butler Yeats, "The Second Coming," in Oscar Williams, ed., The Pocket Book of Modern Verse (New York: 1977), 130.

4"Pastoral Constitution on the Church in the Modern World," in Austin Flannery, ed., Conciliar and Post-Conciliar Documents (Collegeville: 1975), 903-11.

5"Justice in the World," Statement of the Second General Assembly, Synod of Catholic Bishops in Vatican City (1971), no. 6, reprinted in The Gospel of Peace and Justice, edited by Joseph Gremillion (New York: 1975), 514.
} 
As a reconciler, one who harmonized and related varied and at times conflicting forces, Vincent lived the Christian theme of reconciliation. In his opening address to the recent Synod on Reconciliation, Pope John Paul II noted that "reconciliation makes a man pass from one mode of existence to another." He also noted that it is only reconciliation which will lead to a renewal of society on a moral basis. The archbishop of Liverpool in his synodal presentation also captured the essentially Vincentian aspect of reconciliation by saying that "the Catholic Church's work in reconciliation is most effective when she becomes involved in the actual daily issues where the effects of sin leave the human face marked with tears of pain." ${ }^{\prime \prime}$

The etymology of the word "reconcile" gives us insights into this theme because the root word is cilium, the Latin word for eyebrow or eyelash. To be reconciled, then, is for one to be again at eye level with another, the position of equality for all people under God. This vision requires creativity; thus we can remember Vincent de Paul as a creative reconciler, a man committed to and successful in seeking to transform society into the Kingdom.

\section{Parallels of the Seventeenth and the Twentieth Centuries}

Before we look closely at Vincent as the creative reconciler, let us determine the similarity of France and the Catholic Church of the seventeenth century with our own, contemporary American scene. The parallels are striking! Political and economic structures were changing in the seventeenth century as the social-political organization was yielding to a more modern form in a way that parallels our transition from a production-industrial society to the service-information society. France was then in a world leadership position politically and ecclesially as we are now as well. The eldest daughter of the Church was. the opinion maker and the power wielder. The seventeenth-century Church was also post-conciliar as we are. It was responding to the calls of the Council of Trent, which closed in 1563 after nineteen years and twenty-five sessions. The major objective of that council was to bring unity and stability to the Church which had just undergone the shock

'Derek Worlock, "Sacramental Reconciliation's Link with the World," Origins 13 (3 November 1983):353.

${ }^{7}$ For a popular history of the events in Saint Vincent de Paul's life, see Henri Daniel-Rops, Monsieur Vincent (New York: 1961), 71; for a scholarly presentation, see Pierre Coste, The Life and Works of Saint Vincent de Paul. Trans. by Joseph Leonard, C.M. 3 vols. (Westminster, Maryland: 1952). 
of Reformation. Just as in our post-Vatican II day, we are seeking new understandings of the church-state relationship, the relationship of moral teaching to political issues, post-Trent France was also seeking a contemporary interpretation of "render to Caesar the things that are Caesar's and to God the things that are God's." Another pointed but less dramatic similarity between the two post-conciliar periods is the great stress laid on the necessity for good sermons and the preparation of priests as effective proclaimers and appliers of the Word of God.

Peace, then as now, was a greatly sought after goal. Vincent himself lived through the Thirty Years War and the civil war known as the Fronde, as well as a good many Church controversies. France was then awash with blood, just as many parts of the world are today with territorial rights serving as the primary power and economic imperative.

Family life was in such disarray that the Council of Trent had to stress the sacramental nature of marriage. Henri Brémond, an historian of that era, observed that the seventeenth century, and Trent in particular, reacted strongly to the sexual excesses of the Renaissance, which negatively impacted the family. Americans, especially those engaged in social ministry, are very familiar with the effects of domestic stress and this family breakdown parallel. We are now experiencing the general disappearance of the extended and the nuclear family with the fractured family emerging as the norm. A recent study showed few of our families as "traditional" in having a mother and father who are natural parents of children living within the same household. The abandonment and mutilation of children, very frequently prompted by economic reasons in the seventeenth century, may have exceeded our astonishing rates of child abuse and runaway children, but a parallel still exists. While many children in the seventeenth century were sold and mutilated to earn more sympathy and thus more "charity" for their "beggar-guardians," we may have a more shocking social reality in the very high and rising death rate among youths fifteen to twenty-four, most of which is accounted for by the high suicide rate. While we do not have comparative statistics, one can assume that "the feminization of poverty" is a greater concern to us than it was in Vincent's day, as is the great problem of elder abuse, because of our lengthened life expectancy, but Vincent knew that type of social misery as well.

The seventeenth century also faced the challenge of resettling refugees escaping from economic or political oppression, inadequate health care for the poor, a high level of unemployment, poor housing, 
and, of course, an astounding rate of malnutrition. It is significant to note also that the council fathers of Trent, just as the council fathers of Vatican II, were urged to "exercise a paternal care for the poor and all other unfortunate people." This may be interpreted as the seventeenth century equivalent of a preferential option for the poor.

The parallels are many, and while we must make the historical accommodations required by the passage of more than 300 years, we can be confident that the man Vincent was a man who experienced much of the anguish we experience. His response was positive and constructive because he was a reconciler, a creative reconciler. We remember Vincent because he was a man who could look at the complex, difficult problems of his time and ask, "why?" but quickly look at the good will, genius, and talent of many around him and say, "Wecan and will solve them." The person of creativity sees relationships, new possibilities where the non-creative person is limited by the current reality and is paralyzed by challenges. The creative reconciler we find in Vincent is one who is not frustrated or discouraged by diversity of view, magnitude of needs, complexity of problems, but one who, with God's grace, sees his role as a new creator forming a better world and being energized by the Spirit.

\section{The Dynamic of Creative Reconciliation}

What dynamic was operative in Vincent that prepared him to be the creative reconciler, the one who could bypass both the canon law and ecclesiastical opinion of his day to establish a group of women (the Daughters of Charity) who would live and work outside traditional convents? What dynamic energized him so that he constructed an effective delivery of social services and revolutionized ministry and priestly formation?

As we review history, one is struck by the fact that Vincent took his model of creativity as much from Jacob of the Old Testament, who deceived his blind father, as from Zaccheus of the New Testament, who found climbing a tree the best way to get Jesus's attention. The foundation of the Daughters of Charity on 29 November 1633 demonstrated his creativity. With the assistance of Louise de Marillac he succeeded in a bold innovation. Vincent's friend, Saint Francis de Sales, the bishop of Geneva, working with another widow, Saint Jane Frances de Chantal, tried earlier to get a group of women to work actively in service to the poor, but the Church quickly placed them behind a cloister. Vincent, with his careful selection of language, called the Daughters' place of 
residence a house and not a convent, had them dress in the peasant style of the day rather than in traditional habit and veil, directed them to use the parish church and not have a chapel, and had them make promises of one year rather than perpetual vows. Vincent, by doing all these clever, creative things, took the steps which made possible active communities of religious. He combined a human need and an elastic reading of canon law to respond to the needs of the poor, even while respecting the limited view of women held by the hierarchy. He also democratized religious life by uniting the peasant and working class women with the upper class to share in ministry and become truly sisters in service. His two communities, the Daughters of Charity and the Congregation of the Mission, have survived beyond the average 300 year lifespan of religious congregations and have even generated offspring in the Saint Vincent de Paul Society.

Basic to Vincent's creative reconciliation was basic human struggle - another reconciliation. Vincent had to relate his early-life strong personal ambition for success and riches with his mid-life equally strong desire for service. It was this dialectic, an awareness of his own sin and unworthiness, that caused him to experience personally the extremes of egotism and altruism, a life directed only to himself and one directed totally to God in others and to others in God.

As the third child of a poor Gascon peasant family, Vincent was gifted with an agile mind, creative imagination, and great ambition. Early in life he saw a clerical career as the quickest and best social ladder. His parents, like so many seeking the best for their children, made phenomenal sacrifices to finance his priestly education, even making the supreme sacrifice of selling oxen to meet tuition payments. For a peasant farmer this action was a very large mortgage on one's earning power and farm productivity. Regret over his youthful desire for advancement was so deep that Vincent felt compelled in his later years to tell of his sin of pride by repeating one story. He often admitted that once, when his father arrived at the seminary to visit him, Vincent, ashamed of his father's peasant appearance and crude ways, made an excuse so that he would not have to be seen by his peers in the company of such a disreputable man. This Vincent had a remarkable skill for identifying and using the power brokers of his day. In his early life he used them to climb the social ladder; in his later life he motivated them to help others ascend that ladder.

Historians all agree that there is little of the saint in the early, ambitious Vincent, the Vincent who managed to be ordained a few 
years before the legal age of twenty-four and although ordained for the diocese of Dax, saw more opportunity in Paris and thus made that his goal. Vincent in his later years described his early ambition which caused him to patronize the powerful and the rich "as being caught up in the web of a spider." Remembering this, however, should be encouraging because we, like Vincent, fail often and echoSaint Paul, "That which I would not do, I do; that which I would do, I do not."

By the age of thirty, Vincent had had a very exciting and full life, including a term of slavery and the chaplaincy to Queen Marguerite of Valois. The spiritual guidance of Cardinal Pierre de Bérulle and Saint Francis de Sales assisted Vincent to convert his selfish ambition into humble service. It is important to note that it took deep personal anguish, including the bearing of a slanderous accusation that he had stolen a large sum of money, as well as a terrible struggle in faith, that caused him to turn to his work for the poor. He learned that one must be led through God's will and that all talents are given for only one purpose: to serve. He learned the lesson of stewardship: one receives one's talents to use them and to give them back to the master, the source of all things. He understood the scriptural paradox that leadership is servanthood; in being small we become great; in dying, we live.

One suspects, too, that it was only the great Gascon humor which allowed Vincent to appreciate his own personal history, to laugh at his past, forgive himself and move forward. Many stories illustrate this humor. The historian, Henri Daniel-Rops, speculates that the smile which played ceaselessly around Vincent's mouth was his humor at the wise man who had emerged from the proud youth. When Queen Anne of Austria in her regal chambers commented on Vincent's frayed, faded cassock, the man who early in life dreamed about greatness and status and impressing others could say with directness and humor, "There are neither holes nor stains, Madame." His words were sharper when he was involved in the great Jansenist heresy and was asked to comment on Antoine Arnauld's teaching that he should not go to communion frequently because of unworthiness. Vincent noted that Arnauld wrote and spoke well but that despite his tirade against frequent communion, he himself, of course, received communion at his daily mass.

It is a great irony that while Vincent sought greatness he never achieved it; when he sought God's will, success and greatness abounded. 
However, the Gascon peasant was drawn by the attraction of status and prestige to gain a variety of skills and experience, as well as an array of academic credentials in theology and canon law, all of which he used when he became the man who did not need or desire trappings.

\section{Vincent as Reconciler of Works of Charity and Justice}

Let us now look at one of Vincent's great achievements in creative reconciliation, that of reconciling the church role as agent of justice and charity. Vatican II and the Bishops' Synod in 1971 stressed the need for the Church to work for justice as well as doing works of charity, "Action on behalf of justice and the transformation of the social order is a constitutive dimension of the preaching of the Gospel, or in other words, of the Church's mission for the redemption of the human race and its liberation from every oppressive situation." ${ }^{9}$ While the concept tends to polarize in today's Church, Vincent found a way to relate the two concepts of ministry, what some now dichotomize as the ministry to people and the ministry of issues. Perhaps it was Vincent's dual experience as the oppressed (his poverty, his slavery) and the potential oppressor (his ambition, his drive) that made him so conscious of the need to assure that Christian values informed all systems and structures.

This Church shift from a charity emphasis to justice emphasis has represented a change from dealing with the effects of injustice by providing services to the needy to an analysis of the reasons why one has to do charity and then correcting the causes which require charity. It is a commonplace to look at Mother Theresa as a model of charity, as she gives comfort and consolation to the abandoned dying while Bishop Helder Camara serves as the model of justice as he seeks various political and economic reforms that will achieve equity for his people in Latin America. Vincent opted not to choose between the two but to see his ministry as two sides of one coin. He creatively coordinated efforts so that the charity was offered to those who needed it but the power structures were also dealt with so that justice could be achieved.

The charitable works of Vincent are numerous and well known: homes for the foundlings, homes for orphans, nursing of the sick in their homes and on the battlefield, care of refugees, the establishment of hospitals for the physically and mentally ill, schools, and homes for the

"'Justice in the World," 514 
aged. His works for justice are not so well known, but it was the combination of the two that made his ministry effective. Basic to all his activities were three convictions which grew out of his incarnational theology.

(1) Each human person has dignity and value.

(2) Each human person has a right to what is necessary for his human development.

(3) All of society has a responsibility to see that the aforementioned are realized.

These convictions mirror the statement of Vatican II: "The social order and its development must unceasingly work to the benefit of the human person. . . This social order requires constant improvement." It was these same convictions that caused Vincent to say to many of the affluent and powerful of his day: "Be willing to share the blessings and talents you have with those who are less fortunate," just as modern popes challenged us to give of our substance, not only of our abundance.

A hungering after justice caused Vincent to influence directly the structures of his day. A few incidents will suffice to illustrate his method. To prevent greater corruption among the young, he insisted that the juvenile delinquents be separated from the hardened criminals among the galley slaves. He also worked to get chaplains for the prisoners because of their right to spiritual guidance. Again, to stop the begging in Paris, the government decided to open a general hospital where the sick beggars would be obliged to report for admission, while the healthy ones were to be driven from the capital or be put in a workhouse. Vincent refused to cooperate in this project because it denied an individual his rights. He would not allow his priests to become involved, and thus this plan was weakened and then aborted. On the other hand, he was innovative enough to establish petites ménages, in which old couples could live out their days together and not be consigned to different houses for the poor elderly, while at the same time he also sought to influence policy so that this option would be generally available.

One of the more dramatic stories of Vincent's attempt to influence public policy came during the Fronde. The city of Paris was blockaded by the armies of the crown, and the citizens were starving. Cardinal Jules Mazarin, the major perpetrator of the war and Queen Anne of Austria's advisor, was safely outside Paris. Vincent was sixty-nine at the time but so distressed by the plight of the poor in Paris that he broke through the lines of both the armies of the Fronde and the queen and 
pleaded for hostilities to cease. His message to the queen was direct: peace will be restored when Cardinal Mazarin is dismissed as your chief minister. He also pleaded directly with Mazarin to resign. This took great courage because Vincent knew he ran the risk of the dissidents' misinterpreting his visit to the queen. This they did and retaliated against Vincent's Congregation by sacking the motherhouse of the Priests of the Mission and pillaging one of the community's farms.

It was this same sense of justice that stimulated Vincent to seek a generous response from the wealthy who he feels should give of their abundance. Madame de Gondi, the wealthy wife of the general of the galleys and in whose home Vincent worked as chaplain and as tutor to the young Gondis, was totally converted by Vincent. She was so impressed by one of his sermons that historians tell us she sacrificed little pleasures, reduced expenses on clothes, and put aside 15,000 francs, a considerable sum of money, to establish works for Vincent. He was equally direct with Queen Anne of Austria, but when she hesitated to contribute to his works, Vincent, with great diplomacy but also with great force, challenged, "A queen has no need for jewelry." Not only did Queen Anne then give her diamonds to Vincent for his works, but she became one of the first Ladies of Charity, a group of laywomen dedicated to serving the poor in their homes and who now serve in a variety of ways throughout the world. The marriage of charity and justice is very striking in the image of the upper class women and royalty bending to give soup to a poor sick person in a dirty, unkept back quarter of Paris.

Vincent's sense of justice made him strong in demanding that persons receive what we would call today holistic care. He challenged his early sisters to be sure that the body, mind, and spirit were ministered to. "If you think only of giving them food, medicine, and other things that pertain to the body, you have not fulfilled your obligations." To assure that the system would provide this, Vincent had precise rules and regulations drawn up to assure spiritual care and high standards of physical care. Although we may question the nutritional appropriateness, we must marvel at the detail and the precision of his efforts at standardization (the quality assurance of our own era), which Vincent incorporated into the rules for the Confraternities of Charity.

Each sick person would have as much bread as he needs, with a quarter pound of boiled mutton or beef for dinner, and the same amount of roast for supper; except on Sunday, when they may be given some boiled chicken for their dinner, and two or three times a week, their meat may be 
chopped. Those who have no fever should have a pint of wine each day, half in the morning and half in the evening. On Fridays, Saturdays, and other days of abstinence, they should have two eggs and soup and a little slice of butter for dinner, and the same quantity for their supper, adjusting the number of eggs to their appetites. ${ }^{10}$

Directions were equally explicit for the letting of blood, use of leeches, setting a napkin down to assure cleanliness, etc., and attending to spiritual needs.

It was also this sense of justice which caused Vincent to see all the poor as "deserving." Vincent assumed that all persons wanted to improve their lot, even as he had desired it, and thus he followed that maxim that is now so popular: "It is better to teach a man how to fish than to give him a meal of fish." When he provided war relief to the provinces of Lorraine, Picardy, and Champagne, he established soup kitchens, clinics, etc., but he also insisted that farm implements and seed be distributed in an orderly fashion so that the peasants could again know the dignity of providing for themselves. It was also the reason he insisted that the poor country children be taught to read and that the poor hear the gospel from qualified, prepared priests.

\section{Creative Reconciler/Resource Developer}

Vincent's motivation grew out of the contemporary social need and his own spirituality, while his method grew out of an extraordinary organizational skill. In our day, when we are constantly reminded of the bankruptcy of leadership and we see such high levels of organizational and interpersonal conflict, it is refreshing to remember a man who was a consummateleader, manager, and administrator. The business school manuals could takea page from Vincent's life. He was a superb resource coordinator and a marvelous motivator. He was able to assess each individual's talents and then, in the language of the trade, "play the strengths." Perhaps his greatest success was in selecting Saint Louise de Marillac to be his collaborator in the forming of the Daughters of Charity and the Ladies of Charity. No historian has yet been able to determine which of the two was the stronger force, but all agree that the combination was unbeatable and speaks to the world today of the complementarity of the masculine and feminine styles. The combina-

${ }^{10}$ Daniel-Rops, Monsieur Vincent, 71. 
tion of the peasant Vincent with the aristocratic Louise provides effective modeling of the complementarity of social classes as well.

Vincent's organizational and managerial skills are to be admired as they demonstrate his creativity and his reconciliation skills, but they particularly reveal Vincent's ability to motivate and lead and bring together various constituents in the common mission of social development. Vincent had the ability to gain the support of the rich to assist the poor and a compulsion to bring the rich to God in the poor. Unlike the prophets of theOld Testament and even his near contemporary, François de Fénelon, archbishop of Cambrai, who berated the rich from the pulpit, Vincent recognized the goodness of all, even the royalty and the affluent, and capitalized on their generosity. He, like his friend Francis de Sales, knew that honey is a better motivator than vinegar. He understood the wisdom of what Cardinal John Henry Newman said many decades later, that when we change slowly, we take more people with us. From the first challenge to the middle class and the poor in that Sunday morning sermon at Châtillon-les-Dombes, when he moved the whole congregation to assist a poor sick family, even to his last days, Vincent heightened the awareness of the rich to their need to be their brother's keeper whenever and wherever he needed helping.

Just as Vincent was able to unite the economic classes, represent the governed to the governing, Vincent also is a model for the lay collaboration which we talk about so much today. Vatican II, the bishops' pastoral, "Called and Gifted: The American Catholic Laity," and now the New Code of Canon Law all present an ideal in the twentieth century which Vincent made real in the seventeenth century. His first collaborator, Louise de Marillac, was a lay woman. His first association was the Confraternity of Charity, in which the laity combined resources and efforts to assist the poor. With the help of Saint Louise, he organized the Ladies of Charity, all lay and all of the upper class, and gave them very precise rules and regulations so that service would be standardized and accountability would be assured. In working with many of the tradesmen and farmers of the day, Vincent encouraged them to take in the uneducated and the unskilled (their social inferiors) and assist them to gain the skills required for productive living. Vincent was convinced himself and convinced others that solid spirituality for all who called themselves Christian must be evidenced in religious devotion which issues forth in good works. Vincent convinced those he contacted of the piercing quality of the scriptural question: "How can a man say that he loves God whom he has not seen if he does not love his neighbor whom 
he has seen?"11 He knew well that prayer is validated only by one's treatment of others.

Vincent was a motivator, facilitator, and organizer par excellence. From a small but effective networking of diverse, talented, committed persons, he revolutionized and vitalized the Church and her service. He used well the "grassroots movements," that people like Naisbett and Toffler now tell us are the wave of the future, and he used his political and social influence at all levels.

\section{Relevance of Remembering}

We began this article by asking the questions: why do we remember? do persons influence history? I would now like to give one response to those two questions. We remember so that we may continue the memory and the past heritage by living the legacy today. I would like to suggest three particular challenges the seventeenth-century Vincent puts to us in the twentieth century. I use the Trinitarian model because Vincent had great devotion to the Holy Trinity because he understood that Jesus became man because of the great love of the Father in the Spirit, and thus saw ministry, human services, as incarnational. Just as Jesus assumed flesh, so each person is Jesus in herself/himself and to each other.

(1) We must have the vision to see the world as a totality, to have a cosmic vision which sees all persons and things united in the Creator, Redeemer, and Sustainer. We must see the care and works that we do as responding to the totality of the person, the person as body, mind, and spirit. In our provision of service, we must look beyond individual wholeness to familial and social wholeness. We must see wellness, physical and spiritual, as part of our mission and should promote projects which encourage personal and societal wellness.

(2) We must relate our roles of justice and charity. We must serve and seek system change even as we minister to the victims of those structures which make our charity necessary. Like Vincent we must serve the sick, the poor, the alienated, the lonely, the unemployed, the grieving, the hungry, the dying. While we become their voice with the power brokers, we must in the spirit of Vincent seek reconciliation and not allow division. The transformation of society, the kingdom of justice and peace, begins with the renewal of the individual. 


\section{4}

(3) We must come to a new understanding and living of collaboration -- the effective blending of talents, possessions, and visions in a shared vision for a common mission. Competitiveness, turf issues, frictions disappear within the Vincentian spirit which is based on the centrality of the Kingdom to our actions. Such collaboration of clerics, religious, and laity will be at the service level and the advocacy level, living charity and seeking justice after Vincent's example.

Why do we remember Vincent de Paul? We remember him because he made the times and influenced history. The challenges of our contemporary society could lead us to despair or indifference; but we remember that our religious/political/social/economic environment is not unlike the one in which Vincent lived. That environment called forth in Vincent such active, creative reconciliation that 350 years later groups are assembling all over the world to praise a man who grew from an all too real humanity into a great sanctity and who achieved his greatest works after he reached forty-five.

Vincent was fond of saying that "three can do more than ten when our Lord lends a hand." His was a minority voice, but it was heard and continues to be heard far and wide. Today, the Vincentian family, of which all social service workers and advocates are members, is also a minority. The term "Abrahamic minority" has become popular with both sacred and secular writers. Vincent, like so many of our own contemporaries, knew that it would be an Abrahamic minority which would save the world. Vincent, like Cardinal Basil Hume 350 years later, knew it is better "to anguish in Abraham's tent than to sit secure in Solomon's temple." Let us remember Abraham and Vincent as men of faith, of vision, of creativity, and of reconciliation. It is their memory which will cause us to profess faith, live charity, seek justice, and generate hope. 